\title{
Evaluation of dietary supplementation of L-lysine and phytase in corn gluten meal-soybean meal based diets for Pacific white shrimp Penaeus vannamei (Boone, 1931)
}

\author{
K. MANIKANDAN* AND N. FELIX \\ Directorate of Incubation and Vocational Training in Aquaculture, ECR-Muttukadu, Chennai - 603112 \\ Tamil Nadu, India \\ ${ }^{*}$ Dr. M. G. R. Fisheries College and Research Institute, Ponneri, Chennai - 601 204, Tamil Nadu, India \\ e-mail:mani.ayyap@gmail.com
}

\begin{abstract}
An eight-weeks feeding trial was conducted to study the effects of dietary L-lysine and/or phytase supplementation in corn gluten meal-soybean meal (CGM-SBM) protein blend diets on the growth, apparent digestibility, whole body chemical composition and digestive enzyme activity of Pacific white shrimp Penaeus vannamei (Boone, 1931) juveniles. Five isonitrogenous and isolipidic diets were formulated viz., control diet (T0), with $20 \%$ fishmeal was compared against four CGM-SBM based diets, T1 with no supplementation, T2 supplemented with L-lysine, T3 supplemented with phytase and T4 supplemented with L-lysine+ phytase. Dietary lysine supplementation had a significant effect $(\mathrm{p}<0.05)$ on growth performance and feed conversion ratio (FCR), while supplementation of dietary phytase had no effect on growth performance. Apparent digestibility coefficient (ADC) value for crude protein increased by 2.5 to $3 \%$ on supplementation of phytase (500 FTU kg-1 feed) in the diets. The protein digestibility increased by 8 to $11 \%$ with the addition of dietary phytase than other treatment groups with no supplementation of phytase. The amylase and lipase enzyme activity of T3 and T4 supplemented with dietary phytase was higher than the groups that were not supplemented with dietary phytase. Higher protease activity was observed in T2 diet supplemented with dietary L-lysine. L-lysine and phytase supplementation in plant based CGM-SBM protein blend diets resulted in better growth performance of $P$. vannamei.
\end{abstract}

Keywords: Apparent digestibility, Corn gluten meal-soybean meal based diet, Digestive enzyme, Growth performance, L-lysine, Penaeus vannamei, Phytase

\section{Introduction}

Feed is the most significant aspect to be considered in aquaculture, as it alone contributes to about $60 \%$ of the total cost. Effective usage of raw materials in formulated diets relies on their digestible nutrient and energy prerequisites. Formulation issues, specifically the supply of species specific feeds to meet the nutritional requirements of various developmental phases of the farmed species, remain an essential topic for both commercial and farm made feed production sectors. Nutrition and feeding of Penaeus vannamei (Boone, 1931) has received lot of consideration in the past two decades.

For the culture of aquatic species, the most nutritious and palatable ingredients in the feeds are fishmeal and fish oil (FAO, 2016). Presently the use of fish meal in the compounded feeds is reducing significantly which has shown a perfect descending trend due to higher prices of fish meal in the market (Hardy, 2010). Owing to the increasing trend in cost of fish meal, many studies have been carried out on replacement of fish meal with alternative feed ingredients in aquaculture feeds. Plant protein sources are considered as the best replacement to fish meal; but they do have contrasting characteristics to those of fish meal. The reason is the presence of anti-nutritional factors (ANFs), deficiency in certain essential amino acids, low nutrient digestibility due to lesser bioavailability of nutrients and lesser palatability because of excessive amounts of insoluble carbohydrates mainly consisting of starch and fibre.

While considering the plant protein sources, the most commonly used ingredient in the diet is soybean meal due to its market availability, high nutritional value, well balanced amino acid profile and lower cost (Pereira and Oliva-Teles, 2003). The low protein content in several grain legumes limits their use as alternative plant protein sources. Among the high protein content ingredients, corn gluten meal (CGM), a byproduct which remains after the extraction of starch from corn, could be an excellent replacement ingredient as the fibre content is low, has no anti-nutritional factors and the amino acid content is also higher than that of soybean meal. It has sufficient amount of indispensable amino acids, except for arginine and 
lysine when compared with other alternative diets (Pereira and Oliva-Teles, 2003).

One of the major anti-nutritional factors to be considered while opting for plant protein sources, is phytic acid, which contributes about $1-2 \%$ in most of the oilseeds and cereals. With six phosphate groups and a polyanionic molecule, it is known as inositol hexakisphosphate in free form and phytate in its salt form and serves as a phosphorus (P) store in plants (Kumar et al., 2012). Almost half of the phosphorus in the plant ingredient are bound to phytate, making it unavailable to monogastric animals. This phytate-phosphorus, when released in the aquatic environment, becomes a pollutant. Phytase, known as myoinositol hexaphosphate phosphohydrolase is an enzyme required to hydrolyse the phytate that is indigestible and helps in the release of P. The use of phytase enzyme as a supplement in the diet has been reported since the 1990s. Since shrimps are monogastric animals, they cannot produce the phytase enzyme and hence have to be supplemented through the diet. The use of exogenous phytase will help to improve $P$ bioavailability and helps to break complex materials having minerals.

The insufficient levels of essential amino acids in plant based protein ingredients can be resolved by supplementation of amino acids like lysine and methionine in the feeds. The aim of the presnt study was to evaluate the effects of supplementation of L-lysine and phytase in CGM-SBM protein blend diets on the growth, apparent digestibility, whole body chemical composition and digestive enzyme activity in P. vannamei juveniles.

\section{Materials and methods}

\section{Experimental shrimps and feeding trial}

Penaeus vannamei post-larvae (PL 10) were procured from Sunshine Marine Shrimp Hatchery, Mugaiyur, Kancheepuram, Tamil Nadu. Initially, 6000 animals were acclimatised and reared from PL 10 to juvenile stage in the nursery tank $\left(16 \mathrm{~m}^{2}\right)$ with adequate aeration provided round the clock and fed with a commercial diet (Royal Dragon DT312, Shenlong Bio-tech International Co., Ltd.). Shrimps were graded according to the weight prior to the beginning of the experiment. The experimental setup comprised 3 indoor tanks of size $16 \mathrm{~m}^{2}$ with 6 experimental cages ( 1 x 1 x $1.5 \mathrm{~m}$ sized floating nylon net cages) in each tank and 15 plastic troughs of 501 capacity. Before start of the experiment, all the tanks were thoroughly cleaned and disinfected with bleaching powder (33\% active chlorine) and dried well. The experimental cages and troughs were also disinfected with bleaching powder before use. For the study, uniform sized shrimp juveniles $(1.13 \pm 0.08 \mathrm{~g})$ were stocked in the experimental cages and troughs at a stocking density of 50 nos. per cage and 10 nos. per trough for the growth trial and digestibility experiment respectively. Separate troughs were used for conducting the digestibility experiment so as to facilitate easy collection of faeces. The animals were appropriately acclimatised and released slowly into the experimental cages and plastic troughs. The troughs stocked with shrimps were closed with a net to prevent escape of experimental animals.

\section{Experimental diet formulation}

The primary ingredients used for preparing experimental feeds were corn gluten meal, fish meal and soybean meal. Proximate composition of the primary ingredients are given in Table 1. Five isonitrogenous and isolipidic diets were formulated viz., Control (T0), T1, T2, T3 and T4. Control diet (T0), with 20\% fishmeal was compared against four CGM-SBM based protein blend diets viz., T1 without any supplementation, T2 supplemented with L-lysine $\mathrm{HCl}$, T3 supplemented with phytase and T4 supplemented with both L-lysine $\mathrm{HCl}$ and phytase (Table 2). Each ingredient was pulverised individually in a pulveriser and mixed as per the composition shown in the table along with water to make a dough. The dough was then steam cooked at 15 psi for $20 \mathrm{~min}$ in a pressure cooker and pressed through a hand pelletiser with $1 \mathrm{~mm}$ die and dried in sunlight to the desired moisture level. In the case of phytase supplemented diets, the desired quantity of phytase enzyme was dissolved in $50 \mathrm{ml}$ of distilled water and sprayed over the pellets using a vacuum coater (Forberg International AS, Norway) as described by Robinson et al. (2002).

\section{Evaluation of growth performance}

On termination of the experimental feed trial, all the shrimps were starved for a day before sampling. All the experimental shrimps were counted and weighed

Table 1. Proximate composition (dry matter basis) of primary ingredients used in CGM-SBM protein blend diet

\begin{tabular}{llll}
\hline Parameter & Fishmeal & Soybean meal & Corn gluten meal \\
\hline Moisture (\%) & 12.61 & 5.39 & 3.19 \\
Crude protein (\%) & 58.56 & 47.17 & 70.80 \\
Crude fibre (\%) & $<1.00$ & 5.30 & $<1.00$ \\
Ether extract (\%) & 7.62 & 1.52 & 1.99 \\
Total ash (\%) & 19.04 & 7.46 & 1.55 \\
Gross energy (kcal kg-1) & 4116 & 4347 & 5087 \\
\hline
\end{tabular}


Table 2. Ingredient and proximate composition of CGM-SBM protein blend diet

\begin{tabular}{|c|c|c|c|c|c|}
\hline \multirow{2}{*}{ Ingredients } & \multicolumn{5}{|c|}{ Dietary inclusion level (\%) } \\
\hline & Control (T0) & $\mathrm{T} 1$ & $\mathrm{~T} 2$ & $\mathrm{~T} 3$ & $\mathrm{~T} 4$ \\
\hline Fish meal & 20.00 & 5.00 & 5.00 & 5.00 & 5.00 \\
\hline Corn gluten meal & - & 10.00 & 10.00 & 10.00 & 10.00 \\
\hline Cassava & 12.00 & 12.00 & 12.00 & 12.00 & 12.00 \\
\hline Corn flour & 14.74 & 16.62 & 16.96 & 16.62 & 16.96 \\
\hline Soybean meal & 46.02 & 49.32 & 48.75 & 49.32 & 48.75 \\
\hline Palm oil & 1.15 & 1.97 & 1.96 & 1.97 & 1.96 \\
\hline Soy lecithin & 1.00 & 1.00 & 1.00 & 1.00 & 1.00 \\
\hline Vitamin premix $^{1}$ & 0.50 & 0.50 & 0.50 & 0.50 & 0.50 \\
\hline Mineral premix ${ }^{2}$ & 0.50 & 0.50 & 0.50 & 0.50 & 0.50 \\
\hline Chromic oxide $^{3}$ & 0.50 & 0.50 & 0.50 & 0.50 & 0.50 \\
\hline Carboxymethyl cellulose & 1.50 & 1.50 & 1.50 & 1.50 & 1.50 \\
\hline$\alpha$-Cellulose & 2.00 & 1.00 & 0.95 & 0.98 & 0.93 \\
\hline Vitamin C & 0.10 & 0.10 & 0.10 & 0.10 & 0.10 \\
\hline L-lysine $\mathrm{HCl}^{4}$ & - & - & 0.28 & - & 0.28 \\
\hline Phytase $\left(\mathrm{FTU} \mathrm{kg}^{-1}\right)^{5}$ & - & - & - & 500 & 500 \\
\hline \multicolumn{6}{|c|}{ Proximate composition of the diets (dry matter basis) } \\
\hline Moisture (\%) & 8.16 & 9.56 & 10.07 & 11.37 & 8.75 \\
\hline Crude protein $(\%)$ & 35.34 & 34.76 & 34.55 & 34.12 & 34.92 \\
\hline Crude fibre $(\%)$ & 4.60 & 4.82 & 4.74 & 4.55 & 4.40 \\
\hline Ether extract $(\%)$ & 4.64 & 4.44 & 4.70 & 4.58 & 4.68 \\
\hline Total ash (\%) & 7.44 & 7.13 & 7.04 & 7.00 & 6.67 \\
\hline Gross energy $\left(\mathrm{kcal} \mathrm{kg}^{-1}\right)$ & 4168 & 4138 & 4150 & 4142 & 4100 \\
\hline
\end{tabular}

${ }^{1}$ Vitamin premix: Vit. A - 10,000,000 IU, Vit. B-5,000 mg, Vit. B - $5000 \mathrm{mg}$, Vit. B- $6000 \mathrm{mg}$, Vit. B $-6,000 \mathrm{mg}$, Vit. B $-6,000 \mathrm{mg}$, Vit. C - 60,000 mg, Vit. $\mathrm{D}_{3}-2,000,000 \mathrm{IU}$, Vit. E - 10,000 EU, Vit. H - $200 \mathrm{mg}$

${ }^{2}$ Mineral premix: Magnesium - $2800 \mathrm{mg}$, Iodine - $7.4 \mathrm{mg}$, Iron - $7400 \mathrm{mg}$, Copper - $1200 \mathrm{mg}$, Manganese - $11600 \mathrm{mg}$, Zinc - $9800 \mathrm{mg}$, Cobalt chloride- $4 \mathrm{mg}$, Potassium - $100 \mathrm{mg}$, Selenium - $4 \mathrm{mg}$, Calcium carbonate - $27.25 \mathrm{mg}$, Phosphorous - $7.45 \mathrm{mg}$, Sulphur - 0.7\%, Sodium - 6 mg, Calpan - $200 \mathrm{mg}$, Aluminium - $1500 \mathrm{mg}$ and Choline chloride - $10000 \mathrm{mg}$

${ }^{3}$ MP Biochemicals, LLC

${ }^{4}$ Ajinomoto Heartland, Inc., Chicago

${ }^{5}$ RONOZYME® HiPhos, Mahindra Feeds and Foods, Namakkal, Tamil Nadu, India

to estimate the growth performance in terms of final body weight (FBW), weight gain (WG), survival, food conversion ratio (FCR), feed efficiency ratio (FER), protein efficiency ratio (PER), average daily growth (ADG) and specific growth rate (SGR).

Weight gain $=$ Final weight $(\mathrm{g})-$ Initial weight $(\mathrm{g})$

Average daily growth $(\mathrm{ADG})=\frac{\text { Final weight }(\mathrm{g})-\text { Initial weight }(\mathrm{g})}{\text { Experimental duration in days }}$

Specific growth rate $(\mathrm{SGR})=\frac{\ln \text { final weight }-\ln \text { initial weight }}{\text { Experimental duration in days }} \times 100$

Feed conversion ratio $(\mathrm{FCR})=\frac{\text { Total feed fed }(\mathrm{g})}{\text { Total weight gain }(\mathrm{g})}$

Feed efficiency ratio $($ FER $)=\frac{1}{\text { Feed conversion ratio }(\mathrm{FCR})}$
Protein efficiency ratio $(\mathrm{PER})=\frac{\text { Total wetweight gain }(\mathrm{g})}{\text { Dry weight of protein fed }}$

Survival (\%) $\quad=\frac{\text { Final number of shrimps (Survived) }}{\text { Initial number of shrimps (Stocked) }} \times 100$

\section{Proximate and amino acid analysis}

The proximate analysis of the experimental diets and whole body were determined following standard protocols (AOAC, 1995). Amino acid profile of the experimental diets was analysed in Shrimpex Laboratory, Uthandi by High Performance Liquid Chromatography (HPLC).

Faecal collection

The shrimps stocked in the plastic troughs were initially fed at $10 \%$ of body weight and the ration adjusted for every feeding to keep the uneaten feed at a minimum level. Shrimps were acclimatized to the experimental diets for at least a week prior to collection of faeces. Feeding 
and the faeces collection were done thrice a day as per the following schedule. The plastic troughs were siphoned at $07.30 \mathrm{hrs}$ to remove the faeces and moults present, feed was given to the experimental animals after half an hour of siphoning and the remaining uneaten feed and faeces mixture were siphoned at one-hour interval after feeding and were discarded. After two hours of feeding, the first faeces collection was done and the second faeces collection at three hours after feeding. The same protocol was repeated twice and the faeces filtered were washed quickly with distilled water, dried with a filter paper and stored in freezer until analysis as per Cruz-suarez et al. (2009).

\section{Apparent digestibility coefficient (ADC)}

The apparent digestibility coefficient of the experimental diets was analysed using chromic oxide $\left(\mathrm{Cr}_{2} \mathrm{O}_{3}\right)$ as an inert marker at $5 \mathrm{~g} \mathrm{~kg}^{-1}$ of the diet. The concentrations of the nutrients considered and the concentration of chromium in the experimental diets and in shrimp faeces were estimated respectively to determine the ADC (Cruz-suarez et al., 2009).

$$
\mathrm{ADC}_{\text {diet }}(\%)=100-100\left[\frac{\mathrm{Cd}}{\mathrm{Nd}} \times \frac{\mathrm{Nf}}{\mathrm{Cf}}\right]
$$

where, $\mathrm{ADC}_{\text {diet }}(\%)=$ Apparent digestibility coefficient of the diet $(\%) ; \mathrm{C}_{\mathrm{d}}=$ Concentration of chromic oxide in the $\operatorname{diet} ; \mathrm{C}_{\mathrm{f}}=$ Concentration of chromic oxide in the shrimp faeces; $\mathrm{N}_{\mathrm{d}}=$ Concentration of nutrient in the diet; $\mathrm{N}_{\mathrm{f}}=$ Concentration of nutrient in the shrimp faeces.

\section{Digestive enzyme analysis}

Intestines from sampled experimental shrimps were removed aseptically and mixed with $0.25 \mathrm{M}$ sucrose solution using tissue homogeniser and centrifuged at $8000 \mathrm{rpm}$ for $10 \mathrm{~min}$. The supernatant was separated and stored at $-20^{\circ} \mathrm{C}$ until further analysis. The lipase activity assay was analysed as described by Cherry and Crandel (1932). One unit (U) of lipase activity was defined as $\mu$ mol of $0.05 \mathrm{~N}$ $\mathrm{NaOH}$ required to neutralise the fatty acids released during 1 min of incubation with the substrate. Protease activity was determined as explained by Moore and Stein (1948). One unit of enzyme activity was defined as the amount of enzyme needed to catalyse the formation of $1 \mu \mathrm{g}$ of tyrosine per minute. The amylase activity was determined as described by Clark (1964). One unit (U) of amylase activity was defined as the amount of enzyme needed to catalyse the formation of $1 \mu \mathrm{g}$ of glucose equivalent per minute.

\section{Statistical analysis}

Statistical analyses were carried out with the software package SPSS 20.0 (SPSS, Chicago, IL, USA). Data were expressed as means \pm standard error of the mean (SEM) of three replicates. The means were subjected to one-way ANOVA and compared using Duncan's multiple range test.

\section{Results}

Growth performance

The growth performances of $P$. vannamei fed CGMSBM based protein blend diets are presented in Table 3. At the end of $8^{\text {th }}$ week, the mean final body weight of shrimps fed diets T4 and T2 supplemented with dietary lysine was higher than the control diet (T0) with a weight gain of $6.71 \pm 0.22,6.46 \pm 0.20$ and $5.50 \pm 0.15$ respectively. The survival of $P$. vannamei fed CGM-SBM based protein blend diets showed no significant difference $(\mathrm{p}>0.05)$ with the highest survival recorded in T2. FCR, SGR, PER, FER and ADG showed significant $(\mathrm{p}<0.05)$ difference among the treatments. The best FCR was recorded in T2 diet, with FER of $0.77 \pm 0.04$. The highest SGR was observed in T4 and lowest in T1.

Table 3. Growth performance of pacific white shrimp fed CGM-SBM protein blend diet

\begin{tabular}{|c|c|c|c|c|c|c|}
\hline Parameters & Control (T0) & $\mathrm{T} 1$ & $\mathrm{~T} 2$ & $\mathrm{~T} 3$ & $\mathrm{~T} 4$ & $\mathrm{p}$ value \\
\hline Initial body weight (g) & $1.10 \pm 0.05$ & $1.15 \pm 0.02$ & $1.17 \pm 0.02$ & $1.12 \pm 0.02$ & $1.09 \pm 0.02$ & 0.396 \\
\hline Final body weight (g) & $6.61 \pm 0.13^{\mathrm{a}}$ & $6.48 \pm 0.0^{7} \mathrm{a}$ & $7.64 \pm 0.2^{1} \mathrm{~b}$ & $7.38 \pm 0.15^{\mathrm{b}}$ & $7.80 \pm 0.1^{9} \mathrm{~b}$ & 0.001 \\
\hline Weight gain $(\mathrm{g})$ & $5.50 \pm 0.1^{5} \mathrm{a}$ & $5.33 \pm 0.0^{8} \mathrm{a}$ & $6.46 \pm 0 .{ }^{2} 0 \mathrm{~b}$ & $6.25 \pm 0.12^{\mathrm{b}}$ & $6.71 \pm 0 .{ }^{2} 2 b$ & 0.001 \\
\hline Survival (\%) & $85.33 \pm 3.71$ & $90.66 \pm 1.76$ & $94.66 \pm 2.90$ & $91.33 \pm 5.6^{9} \mathrm{a}$ & $86.66 \pm 3.52$ & 0.449 \\
\hline Total biomass gain (g) & $234.23 \pm 3.88^{\mathrm{a}}$ & $241.61 \pm 5.11^{\mathrm{a}}$ & $306.51 \pm 15.16^{\mathrm{b}}$ & $286.44 \pm 12.34^{\mathrm{b}}$ & $290.31 \pm 7.57^{\mathrm{b}}$ & 0.016 \\
\hline Feed intake $\left(\mathrm{g} \mathrm{shrimp}^{-1}\right)$ & $9.36 \pm 0.42$ & $8.78 \pm 0.17$ & $8.42 \pm 0.25$ & $8.78 \pm 0.58$ & $9.21 \pm 0.38$ & 0.485 \\
\hline FCR & $1.70 \pm 0.0^{3} \mathrm{~b}$ & $1.65 \pm 0.0^{3} \mathrm{~b}$ & $1.30 \pm 0.0^{7} \mathrm{a}$ & $1.41 \pm 0.1^{2} \mathrm{a}$ & $1.37 \pm 0.0^{3} \mathrm{a}$ & 0.009 \\
\hline FER & $0.59 \pm 0.0^{1} \mathrm{a}$ & $0.60 \pm 0.0^{1} \mathrm{a}$ & $0.77 \pm 0.04^{\mathrm{b}}$ & $0.72 \pm 0.0^{6} \mathrm{~b}$ & $0.73 \pm 0.0^{3} \mathrm{~b}$ & 0.018 \\
\hline PER & $1.66 \pm 0.02^{\mathrm{a}}$ & $1.76 \pm 0.02^{\mathrm{a}}$ & $2.29 \pm 0.14^{\mathrm{b}}$ & $2.14 \pm 0.17^{\mathrm{b}}$ & $2.14 \pm 0.05^{\mathrm{b}}$ & 0.007 \\
\hline $\mathrm{ADG}$ & $0.09 \pm 0.003^{\mathrm{a}}$ & $0.09 \pm 0.003^{\mathrm{a}}$ & $0.11 \pm 0.003^{\mathrm{b}}$ & $0.11 \pm 0.003^{\mathrm{b}}$ & $0.11 \pm 0.00^{3} \mathrm{~b}$ & 0.001 \\
\hline SGR & $3.19 \pm 0.09^{\mathrm{ab}}$ & $3.08 \pm 0.04^{\mathrm{a}}$ & $3.34 \pm 0.02^{\mathrm{bc}}$ & $3.36 \pm 0.01^{\mathrm{bc}}$ & $3.51 \pm 0.09^{c}$ & 0.007 \\
\hline
\end{tabular}

Values are expressed as mean \pm SEM $(n=3)$ and values with different superscripts indicate significant differences $(\mathrm{p}<0.05)$ as determined by Duncan's multiple range test. 


\section{Whole body composition and amino acid profile}

The amino acid profile of the experimental diets is given in Table 4. The lysine level was significantly lower in the plant based diet without any supplementation when compared with the control diet. Lysine supplementation was done in the diets $\mathrm{T} 2$ and $\mathrm{T} 4$, so as to bring the required lysine level of 2.1 for $P$. vannamei as per the recommendations of NRC (2011). The whole body chemical composition of pacific white shrimp fed CGMSBM based protein blend diets are presented in Table 5. The whole body chemical composition in terms of crude protein, lipid, crude fibre and ash content of pacific white shrimp did not vary significantly $(\mathrm{p}>0.05)$ with the dietary supplementation of lysine and/or phytase. The crude protein content of shrimp whole body ranged from 67.80 to $68.27 \%$, while the crude fibre content ranged from 5.25 to $5.66 \%$. The whole shrimp ether extract value ranged from 5.02 to $5.37 \%$ and the total ash content varied from 12.37 to $12.70 \%$.

\section{Apparent digestibility coefficient}

Apparent digestibility coefficient (ADC) of dry matter, crude protein and phosphorus of CGM-SBM based protein blend diets is given in Table 6. ADC of dry matter was higher in the control diet (T0) and low in the plant protein based diets, whereas the crude protein digestibility was lower in the diets T1 (Plant based diet without any supplementation) and T2 (plant based diet with lysine supplementation) when compared with the control diet (T0), whereas the digestibility increased in the diets T3 and T4 where phytase was supplemented in the diet. Phosphorus digestibility increased by around $11 \%$ in diet T3 and $8 \%$ in diet T4, where phytase was supplemented in the diet.

\section{Digestive enzyme activity}

The digestive enzyme activities of $P$. vannamei fed CGM-SBM based protein blend diets are depicted in Fig. 1. The highest amylase activity in the intestine of $P$. vannamei was observed in T3, which was statistically different $(\mathrm{p}<0.05)$ from the other treatment groups other than control diet (T0). The CGM-SBM based protein blend diet groups supplemented with lysine (T2 and T4) showed higher trends in the intestinal protease activity, whereas T2 group showed significantly higher protease activity than other treatment groups and control. Lipase

Table 4. Amino acid composition of the experimental diets ( $\mathrm{g} 100 \mathrm{~g}^{-1}$ on dry matter basis)

\begin{tabular}{|c|c|c|c|c|c|}
\hline Experimental diet & Control (T0) & $\mathrm{T} 1$ & $\mathrm{~T} 2$ & $\mathrm{~T} 3$ & $\mathrm{~T} 4$ \\
\hline \multicolumn{6}{|c|}{ Essential amino acids } \\
\hline Arginine & 2.50 & 2.34 & 2.31 & 2.33 & 2.30 \\
\hline Histidine & 1.13 & 1.05 & 1.04 & 1.05 & 1.03 \\
\hline Isoleucine & 1.62 & 1.62 & 1.61 & 1.63 & 1.61 \\
\hline Leucine & 2.83 & 3.52 & 3.62 & 3.56 & 3.52 \\
\hline Lysine & 2.18 & 1.86 & 2.12 & 1.88 & 2.11 \\
\hline Methionine & 0.63 & 0.64 & 0.66 & 0.65 & 0.63 \\
\hline Phenylalanine & 1.88 & 2.03 & 2.01 & 2.05 & 1.98 \\
\hline Threonine & 1.39 & 1.40 & 1.38 & 1.40 & 1.37 \\
\hline Tryptophan & 0.41 & 0.40 & 0.38 & 0.41 & 0.38 \\
\hline Valine & 1.82 & 1.79 & 1.80 & 1.80 & 1.79 \\
\hline \multicolumn{6}{|c|}{ Non-essential amino acids } \\
\hline Cysteine & 0.45 & 0.54 & 0.53 & 0.54 & 0.55 \\
\hline Tyrosine & 1.47 & 1.45 & 1.46 & 1.45 & 1.45 \\
\hline Glutamic & 4.84 & 6.15 & 6.13 & 6.05 & 5.89 \\
\hline Aspartic & 3.65 & 3.65 & 3.59 & 3.62 & 3.57 \\
\hline Glycine & 2.08 & 1.56 & 1.54 & 1.53 & 1.56 \\
\hline Serine & 1.64 & 1.78 & 1.75 & 1.74 & 1.75 \\
\hline Alanine & 1.84 & 1.90 & 1.91 & 1.94 & 1.94 \\
\hline
\end{tabular}

Table 5. Whole body chemical composition ( $100 \mathrm{~g}^{-1}$ on dry matter basis) of pacific white shrimp fed CGM-SBM protein blend diets

\begin{tabular}{lllllll}
\hline Parameters & Control (T0) & T1 & T2 & T3 & T4 & p value \\
\hline Moisture (\%) & $7.44 \pm 0.56$ & $7.51 \pm 0.25$ & $8.39 \pm 0.73$ & $6.96 \pm 0.38$ & $7.21 \pm 0.40$ & 0.294 \\
Crude protein (\%) & $68.06 \pm 0.32$ & $68.01 \pm 0.17$ & $67.87 \pm 0.42$ & $68.27 \pm 0.14$ & $67.80 \pm 0.58$ & 0.907 \\
Crude fibre (\%) & $5.66 \pm 0.07$ & $5.25 \pm 0.13$ & $5.41 \pm 0.22$ & $5.50 \pm 0.27$ & $5.49 \pm 0.11$ & 0.633 \\
Ether extract (\%) & $5.02 \pm 0.10$ & $5.37 \pm 0.30$ & $5.16 \pm 0.29$ & $5.21 \pm 0.40$ & $5.34 \pm 0.25$ & 0.905 \\
Total ash (\%) & $12.49 \pm 0.21$ & $12.51 \pm 0.25$ & $12.37 \pm 0.24$ & $12.50 \pm 0.26$ & $12.70 \pm 0.26$ & 0.917 \\
\hline
\end{tabular}

Values are expressed as means $\pm \operatorname{SEM}(n=3)$ and values with no superscripts indicate no significant differences $(p>0.05)$ 
Table 6. Apparent digestibility coefficient of dry matter, crude protein and phosphorus of CGM-SBM protein blend diets offered to $P$. vannamei

\begin{tabular}{lllllll}
\hline Parameters & Control $(\mathrm{T} 0)$ & $\mathrm{T} 1$ & $\mathrm{~T} 2$ & $\mathrm{~T} 3$ & $\mathrm{~T} 4$ & $\mathrm{p}$ value \\
\hline Dry matter (\%) & $42.05 \pm 0.32^{\mathrm{c}}$ & $35.18 \pm 0.24^{\mathrm{c}}$ & $37.73 \pm 0.27^{\mathrm{b}}$ & $34.56 \pm 0.23^{\mathrm{a}}$ & $37.67 \pm 0.29^{\mathrm{b}}$ & 0.0001 \\
Crude protein (\%) & $77.51 \pm 0.21^{\mathrm{c}}$ & $72.80 \pm 0.27^{\mathrm{a}}$ & $74.72 \pm 0.17^{\mathrm{b}}$ & $79.48 \pm 0.15^{\mathrm{d}}$ & $79.72 \pm 0.27^{\mathrm{d}}$ & 0.0001 \\
Phosphorus (\%) & $35.60 \pm 0.31^{\mathrm{a}}$ & $37.14 \pm 1.14^{\mathrm{ab}}$ & $36.43 \pm 0.40^{\mathrm{a}}$ & $39.61 \pm 0.26^{\mathrm{c}}$ & $38.71 \pm 0.32^{\mathrm{bc}}$ & 0.004 \\
\hline
\end{tabular}

Values are expressed as means $\pm \operatorname{SEM}(\mathrm{n}=3)$ and values with different superscripts indicate significant differences $(\mathrm{p}<0.05)$

activity was recorded highest in T3 group and lowest in T1 group which was neither supplemented with lysine nor phytase.

\section{Discussion}

Although fishmeal replacement in fish feed is feasible, production efficiencies are likely to suffer due to higher inclusions of plant based ingredients in aquafeed formulations as plant sources have unbalanced amino acid profile. Poor animal performances have also been linked to plant ANFs (i.e., phytate-P) and poor ingredient digestibility (Francis et al., 2001; Hardy, 2010). These limitations can be addressed by addition of limiting amino acids and exogenous enzymes in the diet blends of the cultured animals (Xie et al., 2016). Though their application in other monogastric animals have been extensively researched, their effects are still inconsistent with fewer published studies in fish (Bedford 2000; Choct 2006; Sinha et al., 2011). The present study included CGM and SBM, in which CGM is deficient in lysine (Saez et al., 2016). The lysine requirement of $P$. vannamei as recommended by NRC was supplemented through dietary L-lysine and phytase to counteract the activities of phytate in the CGM-SBM based protein blend diets.

The final weight gain of pacific white shrimp in shrimps fed diet T1 with 10\% CGM which was neither supplemented with lysine nor phytase was not significantly different from that of control diet having $20 \%$ fishmeal and $0 \%$ CGM. This result is in congruence with the results of Richard et al. (2011) who observed no benefits in the growth performance of tiger shrimp fed diets containing $34 \%$ fishmeal on comparing with diet having $24 \%$ fishmeal and $11 \%$ CGM. The present study is also in agreement with the suggestions of Molina-Poveda

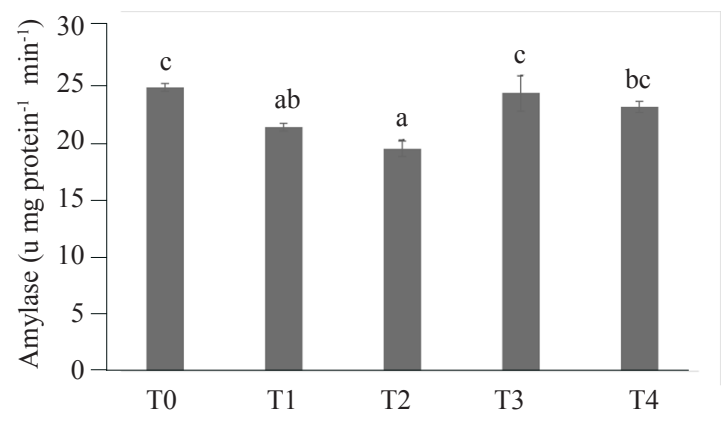

(a)

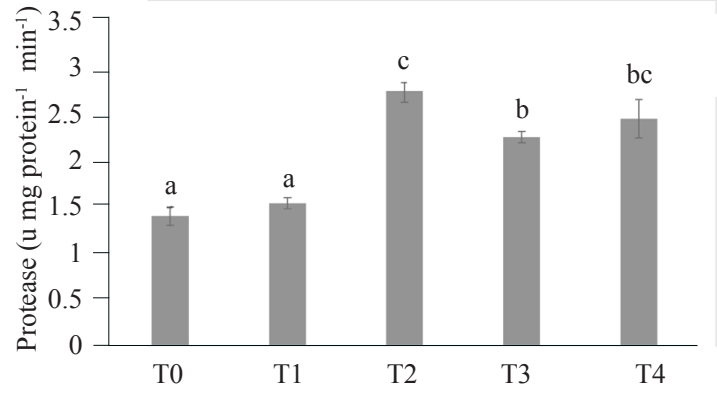

(b)

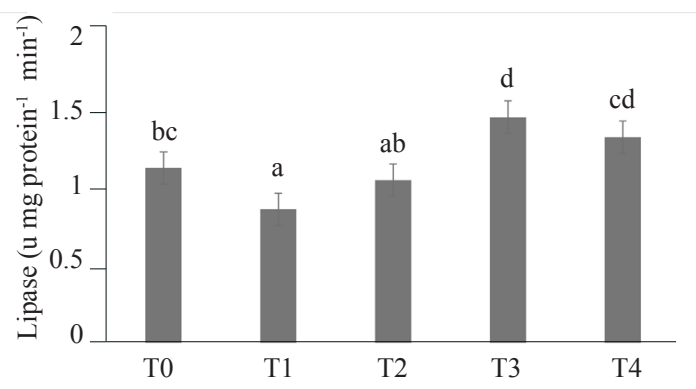

(c)

Fig. 1. Digestive enzyme activities of pacific white shrimp fed CGM-SBM protein blend diets. (a) Amylase activity; (b) Protease activity; (c) Lipase activity. Values are mean \pm SEM represented by vertical error bars for each treatment ( $n=3$ ). Values with different superscripts indicate significant differences $(\mathrm{p}<0.05)$ 
et al. (2015) who indicated that the shrimps would require a CGM inclusion lower than $11 \%$. The final weight of shrimps fed diet T4 supplemented with lysine and phytase and T2 supplemented with lysine alone were higher than that of the control diet indicating that the shrimp growth was higher on supplementation of lysine in CGM-SBM based protein blend diets. This result is in line with the observations of Regost et al. (1999), Pereira and OlivaTeles (2003), Yigit et al. (2012) and Nandakumar et al. (2017). The positive impact of supplementation of L-lysine in the diet on the growth performances are in concurrence with the studies in P. monodon (Milamena et al., 1998; Biswas et al., 2007) and Marsupenaeus japonicus (Alam et al., 2005).

There was no significant difference $(p>0.05)$ in the survival of shrimps fed CGM-SBM based protein blend diets with the values ranging from 85 to $94 \%$, but statistical differences $(\mathrm{p}<0.05)$ were observed in SGR and FCR values among the treatments similar to the results obtained by Molina-Poveda et al. (2015). FCR values were lower in the lysine supplemented diets T2 and T4 which are in line with the results of the studies conducted in tiger shrimp (Biswas et al., 2007) and rainbow trout (Cheng et al., 2003). Higher SGR and PER values in the L-lysine supplemented groups (T2 and T4) indicates the growth promoting effect of dietary lysine supplementation in CGM-SBM based protein blend diets of shrimps which are similar to the results of Biswas et al. (2007). A relatively higher mean final weight in the T3 group could be attributed to higher crude protein digestibility on supplementation of dietary phytase.

Dry matter digestibility decreased in the treatment groups when compared with control group, showing that the digestibility was affected on replacing CGM-SBM protein blend feeds in $P$. vannamei diets. No improvement in the digestibility of dry matter was observed on supplementation of phytase in the treatment groups. This result is contradictory to the studies of Debnath et al. (2005), Baruah et al. (2007), Vandenberg et al. (2012) and Zhu et al. (2014) who observed marked increase in dry matter digestibility on supplementation of phytase.

The addition of phytase neutralises the negative impact of phytic acid on the crude protein and other nutrients in the diets of monogastric animals (Kornegay and Qian, 1996). In the present study, similar results were obtained on addition of phytase to the CGM-SBM protein blend diet for $P$. vannamei. ADC value for crude protein increased by 2.5 to $3 \%$ on supplementation of phytase (500 FTU kg-1 feed) in the diets, which are in line with the studies of Schaefer et al. (1995), Debnath et al. (2005) and Qiu and Davis (2016). Contradictory results on improved crude protein digestibility were observed in several studies. Cain and Garling (1995), Sajjadi and Carter (2004), Liebert and Portz (2005), Baruah et al. (2007) and Vandenberg et al. (2012) observed improved crude protein digestibility while, Lanari et al. (1998) and Riche et al. (2001) observed no improvement in the protein digestibility.

The phosphorus digestibility increased by 8 to $11 \%$ with the addition of dietary phytase as compared to other treatment groups where there was no supplementation of phytase. The results of the present study are in correlation with the studies carried out by Papatryphon et al. (1999), Yoo et al. (2005), Carter and Sajjadi (2011), Zhu et al. (2014) and Cheng et al. (2016), who also reported that phosphorus digestibility improved on supplementation of dietary phytase in plant based diets.

In the present study, the amylase enzyme activity of diets T3 and T4 supplemented with dietary phytase was nearly equal to the enzyme activity of the control diet while the amylase activity level reduced in the groups which were not supplemented with dietary phytase. This result indicates the effect of phytase on the amylase enzyme in the intestine of the shrimp. Similarly, the lipase enzyme activity was reduced in the diets T1 and T2 which were not supplemented with dietary phytase and the activity level increased in the phytase supplemented groups (T3 and T4). Knuckles (1988) correlated the degree of phosphorylation of phytate (myo-inositol phosphate) with lipase activity in in vitro experimental conditions and observed that the inhibition was highly correlated with degree of phosphorylation. The results of the present study are similar to the results observed for both amylase and lipase activity in previous studies (Robaina et al., 1995; Alarcon et al., 1999; Nwanna et al., 2007; Shamna et al., 2015). The protease activity was lower in the control diet as compared to CGM-SBM protein blend diets. Higher protease activity was observed in $\mathrm{T} 2$ diet which was supplemented with dietary L-lysine, followed by T3 and T4 which were supplemented with dietary phytase and lysine+phytase respectively. These results show that the supplementation of amino acid and phytase resulted in increased protease activity similar to the studies of Nwanna et al. (2007) and Li et al. (2009)

Although, the best growth performances were recorded in amino acid supplemented groups of CGM-SBM protein blend diets, combined effects of increased growth, apparent digestibility and digestive enzyme activity were observed in amino acid and phytase supplemented groups of CGM-SBM protein blend diets. Hence the present study concludes that, the supplementation of dietary L-lysine and phytase are required in plant based CGM-SBM protein blend diets for better growth performance of $P$. vannamei. 


\section{Acknowledgements}

The authors sincerely thank National Agriculture Development Programme (NADP/RKVY), Tamil Nadu, India and National Bank for Agriculture and Rural Development (NABARD), India for the financial assistance. We also thank the Directorate of Incubation and Vocational Training in Aquaculture and Tamil Nadu Dr. J. Jayalalithaa Fisheries University, Nagapattinam, Tamil Nadu, India for providing the Indoor aquaculture facility to conduct the experiment.

\section{References}

Alam, M. S., Teshima, S. I., Koshio, S., Ishikawa, M., Uyan, O., Hernandez, L. H. H. and Michael, F. R. 2005. Supplemental effects of coated methionine and/or lysine to soy protein isolate diet for juvenile kuruma shrimp, Marsupenaeus japonicus. Aquaculture, 248(1-4): 13-19.

Alarcon, F. J., Moyano, F. J. and Diaz, M. 1999. Effect of inhibitors present in protein sources on digestive proteases of juvenile sea bream (Sparus aurata). Aquat. Liv. Res., 12(4): 233-238. https://doi.org/10.1016/S0990-7440 (00)86633-4.

AOAC 1995. Official methods of analysis. $13^{\text {th }}$ edn. Association of Official Analytical Chemists, Washington, D.C., USA.

Baruah, K., Pal, A. K., Sahu, N. P., Debnath, D., Nourozitallab, P. and Sorgeloos, P. 2007. Microbial phytase supplementation inrohu, Labeorohita, diets enhances growth performanceand nutrient digestibility. J. World Aquac. Soc., 38(1): 129-137. https://doi.org/10.1111/j.1749-7345.2006.00081.x.

Bedford, M. R. 2000. Exogenous enzymes in monogastric nutrition-their current value and future benefits. Anim. Feed Sci. Technol., 86(1-2): 1-13. DOI: 10.1016/S0377-8401 (00)00155-3.

Biswas, P., Pal, A. K., Sahu, N. P., Reddy, A. K., Prusty, A. K. and Misra, S. 2007. Lysine and/or phytase supplementation in the diet of Penaeus monodon (Fabricius) juveniles: effect on growth, body composition and lipid profile. Aquaculture, 265(1-4): 253-260.

Cain, K. D. and Garling, D. L. 1995. Pretreatment of soybean meal with phytase for salmonid diets to reduce phosphorus concentrations in hatchery effluents. Progr. Fish Cult., 57(2): 114-119. https://doi.org/10.1577/1548-8640 (1995) 057<0114:POSMWP> 2.3.CO;2.

Carter, C. G. and Sajjadi, M. 2011. Low fishmeal diets for Atlantic salmon, Salmo salar L., using soy protein concentrate treated with graded levels of phytase. Aquac. Int., 19(3): 431-444. DOI: 10.1007/s10499-010-9358-z.

Cheng, N., Chen, P., Lei, W., Feng, M. and Wang, C. 2016. The sparing effect of phytase in plant-protein-based diets with decreasing supplementation of dietary $\mathrm{NaH}_{2} \mathrm{PO}_{4}$ for juvenile yellow catfish Pelteobagrus fulvidraco. Aquac. Res., 47(12): 3952-3963. https://doi.org/10.1111/are.12845.
Cheng, Z. J., Hardy, R. W. and Usry, J. L., 2003. Effects of lysine supplementation in plant protein-based diets on the performance of rainbow trout (Oncorhynchus mykiss) and apparent digestibility coefficients of nutrients. Aquaculture, 215(1-4): 255-265.

Cherry, I. S. and Crandall, L.A. 1932. The specificity of pancreatic lipase: its appearance in the blood after pancreatic injury. Am. J. Physiol. Legacy Content, 100(2): 266-273. https:// doi.org/10.1152/ajplegacy.1932. 100.2.266.

Choct, M. 2006. Enzymes for the feed industry: past, present and future. World Poul. Sci. J., 62(1): 5-16. DOI: https://doi. org/10.1079/WPS200480.

Clark, J. M. 1964. Experimental biochemistry. W. H. Freeman and Company, San Francisco, USA and London, UK, 228 pp.

Cruz-Suarez, L. E., Tapia-Salazar, M., Villarreal-Cavazos, D., Beltran-Rocha, J., Nieto-Lopez, M. G., Lemme, A. and Ricque-Marie, D. 2009. Apparent dry matter, energy, protein and amino acid digestibility of four soybean ingredients in white shrimp Litopenaeus vannamei juveniles. Aquaculture, 292(1-2): 87-94. DOI: 10.1016/j. aquaculture.2009.03.026

Debnath, D., Pal, A. K., Sahu, N. P., Jain, K. K., Yengkokpam, S. and Mukherjee, S. C. 2005. Effect of dietary microbial phytase supplementation on growth and nutrient digestibility of Pangasius pangasius (Hamilton) fingerlings. Aquac. Res., 36(2): 180-187.

FAO 2016. The state of world fisheries and aquaculture 2016 Meeting the sustainable development goals. FAO Technical Publication, Food and Agriculture Organisation, Rome, Italy.

Francis, G., Makkar, H. P. and Becker, K. 2001. Antinutritional factors present in plant-derived alternate fish feed ingredients and their effects in fish. Aquaculture, 199(3-4): 197-227.

Hardy, R. W. 2010. Utilisation of plant proteins in fish diets: effects of global demand and supplies of fishmeal. Aquac. Res., 41(5): 770-776. https://doi.org/ 10.1111/j.1365-2109. 2009.02349.x.

Knuckles, B. E., 1988. Effect of phytate and other myo-inositol phosphate esters on lipase activity. J. Food Sci., 53(1): 250-252. https://doi.org/10.1111/j.1365-2621.1988.tb 10221.x.

Kornegay, E. T. and Qian, H. 1996. Replacement of inorganic phosphorus by microbial phytase for young pigs fed on a maize-soyabean-meal diet. British J. Nutr., 76(4): 563-578. DOI: https://doi.org/10.1079/BJN19960063.

Kumar, V., Sinha, A. K., Makkar, H. P. S., De Boeck, G. and Becker, K. 2012. Phytate and phytase in fish nutrition. J. Anim. Physiol. Animal Nutr., 96(3): 335-364. doi: 10.1111/j.1439-0396.2011.01169.x.

Lanari, D., D'agaro, E. and Turri, C. 1998. Use of nonlinear regression to evaluate the effects of phytase enzyme 
treatment of plant protein diets for rainbow trout (Oncorhynchus mykiss). Aquaculture, 161(1-4): 345-356.

Li, J. S., Li, J. L. and Wu, T. T. 2009. Effects of non-starch polysaccharides enzyme, phytase and citric acid on activities of endogenous digestive enzymes of tilapia (Oreochromis niloticus $\times$ Oreochromis aureus). Aquac. Nutr., 15(4): 415-420. https://doi.org/10.1111/j.1365-2095. 2008.00606.x.

Liebert, F. and Portz, L. 2005. Nutrient utilisation of Nile tilapia Oreochromis niloticus fed plant based low phosphorus diets supplemented with graded levels of different sources of microbial phytase. Aquaculture, 248(1-4):111-119. DOI: 10.1016/j.aquaculture.2005. 04.009.

Millamena, O. M., Bautista-Teruel, M. N., Reyes, O. S. and Kanazawa, A. 1998. Requirements of juvenile marine shrimp, Penaeus monodon (Fabricius) for lysine and arginine. Aquaculture, 164(1-4): 95-104. https://doi.org/ 10.1016/S0044-8486(98) 00179-3.

Molina-Poveda, C., Lucas, M. and Jover, M. 2015. Utilisation of corn gluten meal as a protein source in the diet of white shrimp Litopenaeus vannamei. Aquac. Nutr., 21(6): 824-834. https://doi.org/10.1111/anu.12209.

Moore, S. and Stein, W. H. 1948. Photometric method for use in the chromatography of amino acids. J. Biol. Chem., 176: 367-388.

Nandakumar, S., Ambasankar, K., Ali, S. S. R., Syamadayal, J. and Vasagam, K. 2017. Replacement of fish meal with corn gluten meal in feeds for Asian seabass (Lates calcarifer). Aquac. Int., 25(4): 1495-1505. DOI: 10.1007/ s10499-017-0133-2.

NRC 2011. Nutrient requirements of fish and shrimp. National Research Council, National Academies Press, USA

Nwanna, L. 2007. Effect of dietary phytase on growth, enzyme activities and phosphorus load in Nile tilapia (Oreochromis niloticus). J. Eng. Appl. Sci., 2(6): 972-976.

Papatryphon, E., Howell, R. A. and Soares Jr., J. H. 1999. Growth and mineral absorption by striped bass Morone saxatilis fed a plant feedstuff based diet supplemented with phytase. J. World Aquac. Soc., 30(2): 161-173. https://doi. org/10.1111/j.1749-7345.1999.tb00863.x.

Pereira, T. G. and Oliva-Teles, A. 2003. Evaluation of corn gluten meal as a protein source in diets for gilthead seabream (Sparus aurata L.) juveniles. Aquac. Res., 34(13): 11111117. https://doi.org/10.1046/j.1365-2109.2003. 00909.x.

Qiu, X. and Davis, D. A. 2016. Effects of dietary phytase supplementation on growth performance and apparent digestibility coefficients of Pacific white shrimp Litopenaeus vannamei. Aquac. Nutr., 23(5): 942-951. https://doi.org/10.1111/anu. 12462.

Regost, C., Arzel, J. and Kaushik, S. J. 1999. Partial or total replacement of fish meal by corn gluten meal in diet for turbot (Psetta maxima). Aquaculture, 180(1-2): 99-117. https://doi.org/10.1016/S0044-8486(99)00026-5.
Richard, L., Surget, A., Rigolet, V., Kaushik, S. J. and Geurden, I. 2011. Availability of essential amino acids, nutrient utilisation and growth in juvenile black tiger shrimp Penaeus monodon, following fishmeal replacement by plant protein. Aquaculture, 322: 109-116

Riche, M., Trottier, N. L., Ku, P. K. and Garling, D. L. 2001 Apparent digestibility of crude protein and apparent availability of individual amino acids in tilapia (Oreochromis niloticus) fed phytase pretreated soybean meal diets. Fish Physiol. Biochem., 25(3): 181.

Robaina, L., Izquierdo, M. S., Moyano, F. J., Socorro, J., Vergara, J. M., Montero, D. and Fernandez-Palacios, H. 1995. Soybean and lupin seed meals as protein sources in diets for gilthead seabream (Sparus aurata): nutritional and histological implications. Aquaculture, 130(2-3):219-233. https://doi.org/10.1016/0044-8486(94)00225-D.

Robinson, E. H., Li, M. H. and Manning, B. B. 2002. Comparison of microbial phytase and dicalcium phosphate for growth and bone mineralization of pond-raised channel catfish, Ictalurus punctatus. J. Appl. Aquac., 12(3): 81-88.

Saez, P. J., Abdel-Aal, E. S. M. and Bureau, D. P. 2016. Feeding increasing levels of corn gluten meal induces suboptimal muscle pigmentation of rainbow trout (Oncorhynchus mykiss). Aquac. Res., 47(6): 1972-1983. https://doi.org/ 10 1111/are. 12653.

Sajjadi, M. and Carter, C. G. 2004. Effect of phytic acid and phytase on feed intake, growth, digestibility and trypsin activity in Atlantic salmon (Salmo salar, L.). Aquac. Nutr., 10(2): 135-142. https://doi.org/10.1111 /j.1365-2095.2003.00290.x.

Schafer, A., Koppe, W. M., Meyer-Burgdorff, K. H. and Gunther, K. D. 1995. Effects of a microbial phytase on the utilisation of native phosphorus by carp in a diet based on soybean meal. Water Sci.Technol., 31(10): 149-155. https://doi.org /10.1016/0273-1223(95)00434-O.

Shamna, N., Sardar, P., Sahu, N. P., Pal, A. K., Jain, K.K. and Phulia, V.2015. Nutritional evaluation of fermented Jatropha protein concentrate in Labeo rohita fingerlings. Aquac. Nutr., 21(1): 33-42. https://doi.org/10.1111/anu.12138.

Sinha, A. K., Kumar, V., Makkar, H. P., De Boeck, G. and Becker, K. 2011. Non-starch polysaccharides and their role in fish nutrition-A review. Food Chem., 127(4): 1409-1426.

Vandenberg, G. W., Scott, S. L. and De La Noue, J. 2012 Factors affecting nutrient digestibility in rainbow trout (Oncorhynchus mykiss) fed a plant protein-based diet supplemented with microbial phytase. Aquac. Nutr., 18(4): 369-379. https://doi.org/10.1111/j.1365-2095. 2011.00901.x.

Xie, S. W., Liu, Y. J., Zeng, S., Niu, J. and Tian, L. X. 2016. Partial replacement of fish-meal by soy protein concentrate and soybean meal based protein blend for juvenile Pacific white shrimp, Litopenaeus vannamei. Aquaculture, 464:296302. http://dx.doi.org/10.1016/j.aquaculture.2016.07.002. 
Yigit, M., Bulut, M., Ergun, S., Guroy, D., Karga, M., Kesbiç, O. S., Yilmaz, S., Acar, U. and Guroy, B. 2012. Utilisation of corn gluten meal as a protein source in diets for gilthead seabream (Sparus aurata L.) juveniles. J. Fish. Sci., 6(1): 63-73.

Yoo, G. Y., Wang, X., Choi, S., Han, K., Kang, J. C. and Bai, S. C., 2005. Dietary microbial phytase increased the phosphorus digestibility in juvenile Korean rockfish Sebastes schlegeli fed diets containing soybean meal. Aquaculture, 243(1-4): 315-322.

Zhu, Y., Qiu, X., Ding, Q., Duan, M. and Wang, C. 2014. Combined effects of dietary phytase and organic acid on growth and phosphorus utilisation of juvenile yellow catfish Pelteobagrus fulvidraco. Aquaculture, 430: 1-8. 